\title{
Social Assessment and Resettlement Policies and Practice in China: Contributions by Michael M Cernea to Development in China
}

\author{
Guoqing Shi, Fangmei Yu, and Chaogang Wang
}

We are very pleased to contribute to this volume to express our appreciation for the collaboration with the community of social scientists, sociologists and anthropologists, working at the World Bank. Chinese social scientists joined forces with them on essential activities: development projects, research programs, academic conferences, training courses, and joint books. One of us, Guoqing Shi, has participated in the international symposium in Bieberstein, Germany, where this volume has originated.

We begin this paper with some historical information on our first contacts with the World Bank's social specialists. They started to work in China in 1986 to assist us in preparing World Bank-financed development projects for our country. Since then our interactions have expanded to address some of the most complex development issues. We will focus in this article on our collaboration in two such major development domains: (a) population resettlement and how to prevent the impoverishment of displaced populations - a big concern that in China emerged only in mid 1980s; and (b) the promotion of social research in support of development through the introduction of pre-project "social impact assessments," a demand that emerged in China from the State Commission for Planning in the early 1990s.

G. Shi

NRCR, Hohai University, Nanjing, Jiangsu, China

F. Yu

Gulou District, Nanjing City, Jiangsu Province, China

C. Wang $(\bowtie)$

The World Bank, Gaithersburg, MD, USA

e-mail: Cwang3@worldbank.org 


\section{Infrastructure Construction and Population Displacement}

Over the last 40 years, China has achieved a rapid rate of economic development by building up a modern infrastructure across the country: highways, railways, dams, power plants, airports, pipelines, and large industrial zones, as well as new urban infrastructure (housing, schools, universities, hospitals, hotels, markets, malls). This widespread development has also involved a vast amount of population displacement and resettlement. However, in the first three decades after independence, between 1949 and 1980, the state's approach to displacement and resettlement gave one-sided priority to technical infrastructure, without concern for the adverse impacts on the livelihoods of the people displaced (see Chen 2018).

These were openly recognized after the end of the 'Cultural Revolution' in 1980. New social policies were adopted to deal with the adverse impacts of rapid infrastructure construction. An important factor in this process was - also in 1980 - the decision of the PRC Government to join the World Bank. Membership in the Bank opened China's way to learn from the Bank's development policies and experiences (Shi 2010, 2015).

The first projects for which China requested World Bank financing were three hydro-power projects: Shuikou Dam, Ertan Dam, and Yantan Dam. In preparing these projects, the first new idea that China learned from the World Bank was about its historic decision to adopt in 1980 its policy for involuntary resettlement.

For the preparation and appraisal of the first Shuikou Dam Project, the World Bank sent its senior social policy advisor, the sociologist Professor Michael M Cernea, to explain the Bank's involuntary resettlement policy to the high level officials of the Fujian Province, and to officials from Beijing. The appraisal mission brought along the World Bank's two major policy documents on resettlement: the OMS 2.33 (World Bank 1980) and the Operational Policy Note on Resettlement (World Bank 1986). Both policy documents (World Bank 1984, 1986, 1994/1996, 2001) and other important papers (see Cernea 1990, 1991, 1997, 2000, 2004) were translated into Chinese.

During their long meetings over several days discussing the content of the new policy, the Chinese officials concluded that the objectives and requirements of those two policy documents were compatible with China's government, and therefore acceptable for implementation in the Shuikou Dam project. China agreed to develop a Resettlement Action Plan (RAP) to protect the livelihood of the over 80,000 people (both rural and urban) to be displaced and resettled by the Shuikou project. After several days, Michael M Cernea was informed by the Chinese officials that these policy principles would be included also in China's forthcoming new resettlement regulation, which at that time was under preparation in Beijing.

The implementation and outcomes of the resettlement component in the Shuikou Dam became indeed "the best practice" at that time for both the World Bank and China. After the Bank's approval of the Shuikou investment, Cernea continued for several years to observe and study the Shuikou experiment through supervision missions. He and the government derived information and lessons for applying the same Shuikou approach to other resettlement processes in the Ertan and Yantan project resettlements. For the Ertan Dam project, the Bank recommended that China 
invite a well known Norwegian scholar anthropologist, Frederick Barth, who accepted to lead a monitoring and advisory international panel that was of great help. (Barth 2003).

Overall, the resettlement processes at all these three projects marked big improvements compared to the resettlement processes carried out in tens of Chinese project dams completed before 1986. China's government's appreciation for the Bank's policy and staff expertise was also reflected in its request to the World Bank to appoint a panel of five senior staff members to advise the managers of China's Three Gorges Project in the final stage of Three Gorges resettlement planning, as well as to assist China in guiding the resettlement work of the Canada-Yangtze Joint Project (CYJP). Michael M Cernea was the resettlement expert in the Bank-China panel. During the following 4 years he made several field visits in the TGP resettlement areas and participated in the periodic meetings between China and Canada for the conduct of the CYJP project.

The work of the World Bank's resettlement specialists in China in the following years expanded., with other World Bank staff such as David Butcher, Dan Gibson, William Partridge, Scott Guggenheim, Maritta Koch-Weser, Maria Clara Mejia, Gorden Appleby, Richard Manning and many others becoming part of a growing community that could exchange ideas and experience. Our bilateral cooperation also expanded due to the employment by the World Bank of Chinese resettlement specialists like Chaohua Zhang, Youlan Zou, Chaogang Wang, Guoqing Shi, Shaojun Chen, Wenxue Yu, Songlin Yao, Zhefu Liu, Zongcheng Lin, Youxuan Zhu, Heping Gong, Ajiang Chen, Wenlong Zhu and others, either as World Bank staff members in Washington and Beijing, or as external consultants. They worked together both in China on large scale projects such as the Xiaolangdi Hydropower Project (with 200,000 people to be relocated, and the Wanjiazhai project, among others) or as consultants employed on Bank supported projects in other developing countries in Asia and Africa. This cooperation has been highly beneficial in achieving transmission of international experiences as well as leading to more substantive convergence between operational policies.

\section{Research Based Knowledge and Resettlement Science: The Creation and Role of NRCR}

Displacement and resettlement can never be conducted as standard copy-cat programs. Their inherent complexity and diversity is, in each case, amplified by differences in geographic and demographic contexts. This is why carrying out both basic and operational sociological and economic research is indispensable for satisfactory resettlement performance. In China, this truth is not disputed. Academic institutions in China consider the build-up of resettlement research, knowledge, and literature as the emergence of a distinct science sub-discipline: "Resettlement Science" (Shi 1995, 1999, 2009). A new masters and Ph.D program in Resettlement in 
1988 was created in Hohai University and approved by the Academic Degrees Committee of the State Council in 2004.

Beginning in the early 1990s, China has increased its financing for multiplying institutional structures for research and training for resettlement. The first major step was the creation in 1992 of China's National Research Center on Resettlement (NRCR) at Hohai University, in Nanjing, which was entrusted with major tasks at both the national and the international scale. NRCR is directed from its creation by one of the authors of this paper, Professor Guoqing Shi. A number of trained groups for research and planning resettlement were established also within the administrative structure of each of China's Provinces. More recently, a new academic Center for Reservoir Resettlement Research, headed by Professor Yuefang Duan, was created at Three Gorges University, in Yichang.

Besides its basic and operational research responsibilities to develop new knowledge for operational work and for supporting new policy developments, NRCR is also tasked to deliver teaching and training to help create professionally formed specialists in this domain, prepared for working as state officials for jobs related to resettlement or as managers of project resettlement components. NRCR offers a BA program of majoring in resettlement knowledge. It also offers university-based graduate academic training in resettlement science and management, both at the MA and PhD levels. Both an English-language international MA and Ph.D. program in Resettlement Science and Management, and Resettlement Sociology as a sub-program of Sociology attracted dozens of students from Asia, Africa and America to Hohai University since 2013. NRCR faculty and graduate students are participating in development projects in China itself, and also in World Bank and ADB projects with resettlement components in other countries. Thousands of international and domestic students from different universities and institutes have read Michael M Cernea's articles and books and taken them as the degree thesis's references.

NRCR also conducts a broad publishing program of Chinese and international books on resettlement to disseminate knowledge on resettlement and on other development topics to specialists and to the public at large. For instance, during 1995-1998, NRCR and Hohai University Press took the initiative to translate and publish two books of theoretical, methodological, and policy studies on resettlement authored by Michael M Cernea; both books were edited by NRCR's Director (see Shi 1996, 1998). These books are regularly used for training by NRCR and in the provinces of PRC. NRCR is also regularly organizing and hosting international and national conferences on Resettlement with Development; e.g., a major International Conference on Resettlement and Social Development was hosted by NRCR and Hohai University in Nanjing, both in May 2002 and in August-September 2019.

The emerging resettlement science (Shi 2009) is now informing China's policies and laws, and it has influenced Chinese society, decision makers, planners, managers, practitioners, and academics. The most significant event is that China's Academy of Sciences (CAS) submitted in 2012 to the State Council of China a major report, titled: 'Report with Recommendation on Strengthening Research in the Disciplines Relevant to the Social Engineering of Resettlement'. China's Academy is 
emphasizing that the expanding research and the knowledge accumulation on resettlement is evolving into a scientific discipline known as "resettlement science" that requires also a social engineering methodology for being applied in practice. As a consequence, in March 2016 "Resettlement Engineering for Water Conservancy" was introduced as one of 16 distinct disciplines that compose the Water Science and Water Engineering Group of Disciplines, accredited officially by the China's National Council of Sciences and by China's Academy of Sciences.

Based on national academic exchange demand, a new resettlement sociology committee under the Chinese Sociology Association was proposed by Professor Guoqing Shi of NRCR and established in 2008. It is only the second committee approved after 20 years since the Reservoir Resettlement Committee of Chinese Hydropower Engineering Association was founded in 1988.

\section{The Goal of China's Current Resettlement Policy: Legislating the Resettlement with Development Paradigm}

Deriving important legal and economic lessons from research on its own experiences since 1986, China made a continuous series of improvements in its legislation for resettlement. Beginning in 1985, the government decided to initiate a large-scale action for "resolving the remaining legacy from reservoir-caused resettlement" to be financed from a supplementary "special fund" of 240 mil. yuan annually (Duan 2018). This was a shift from the impoverishing practices during the PRC's first 30 years to a nationwide policy characterized in 2006 by China's State Council as the resettlement with development strategy paradigm (State Council of China 2006). Thereafter, China advanced the process of defining and implementing the new resettlement paradigm, which over time became more protective and developmentoriented than the World Bank's OP/BP 4.12 policy in terms of normative protections and economic enhancements provided to involuntary resettlers.

It is important to explain the philosophy that prompted China's leadership to arrive at the Resettlement with Development resettlement paradigm. The central objective of all of China's legislation (not only of that about resettlement) is to provide development benefits equitably to the entire nation. However, the complexity of producing development involves also difficult processes, such as displacement of people, which in itself carries severe impoverishment risks, long-term losses and social upheavals, as described in the "Impoverishment Risks and Reconstruction Model" (IRR) formulated by Michael M Cernea.

Chinese researchers have adopted and used widely the IRR model and identified the presence of these risks in many projects. But if such risks and upheavals are so frequent in many displacement that are inevitable, why not use such displacements deliberately as an opportunity to plan the relocation not simply a geographic move, but also a social and economic reconstruction and step up? This paradigm is asking China's resettlement planners, practitioners, and managers to regard the need to 
displace people as an opportunity to create conditions for the overall advancement of the uprooted population as well, because lifting people from poverty is the ultimate goal of the country's policies and laws. Certainly, this requires investing more financing. But such investments are worth making precisely at this critical disruption moment because they reduce social discontent, alleviates temporary distress, and accelerates the planned development to which those people are fully entitled, and which they expect. This way, in essence the Resettlement with Development strategy rebalances the pains and gains of development between those who benefit and those who are suffering significant losses from displacement, enabling the latter to also benefit.

The core strategy change embedded in the new Resettlement with Development paradigm is to give considerably more attention to the economics, financing, cultural potentials and the logistics of resettlement planning. This requires improved preparation, and involves carrying out, well in advance of resettlement, detailed planning and design for everything needed in terms of community facilities, services, employment opportunities, and family houses at the relocation sites. But what is most important is that sufficient financing must be allotted for investing both in reconstruction and in post-relocation development of resettlers. This orientation places the foremost emphasis on preventing impoverishment by reconstructing a sound productive economic basis for resettlement.

China's determined shift towards resettlement with development has brought with it innovative solutions to the problem of managing large scale resettlement in line with the government's policy prescriptions. For instance, the twin Xiaolangdi projects (advocated inside the Bank by its own social specialists) that were implemented in 1994-2004, consisted of a distinct project for constructing the dam itself, plus a parallel yet distinct project focused only on the relocation and resettlement of nearly 200,000 people. The two projects were legally crosscorrelated but each had a distinct management team that focused entirely on eachone's project, but cross-coordinated the timelines of the twin projects.

These two twinned projects were a major success of China and the World Bank. Both had immense budgets, US $\$ 3.5$ billion and US\$1 billion, respectively. And for China, this was not an isolated case. Cernea's approach to risk analysis is now widely accepted and used by Chinese scholars, resettlement researchers, and practitioners. For example, another very large scale resettlement in the Shiman highway project in Hubei succeeded in alleviating the pre-existing poverty and reducing the risks of creating new impoverishment; also, Liu and Bennett 2008; World Bank 2010). In the second phase of the Danjiangkou Dam Heightening Project, which displaced 345,000 people, most displaced households got the subsidies for new house construction and new, modern community facilities. Within the project's resettlement policy, each displaced person got the construction cost for $24 \mathrm{~m}^{2}$ as a minimum payment.

Nonetheless, implementing each project consistently with the Resettlement with Development paradigm is not always an easy process. The above descriptions reflect the essential content of this paradigm, but creativity in its implementation is a constant requirement and challenge. Departures from this paradigm and 
transgressions of norms certainly also occur in various forms and degrees. Chinese and international scholars who research these projects often signal failures, not only successes.

China's Resettlement with Development model still has broad scope for improvement and being perfected, particularly outside the water sector. Implementation of the Resettlement with Development model is also encountering difficulties and distortions in the practices of some provinces, and various populations of displaced people often still face hardships. As some international experts have written, improvements on a larger scale are needed to broaden participation and response feedback mechanisms; to develop culturally adjusted practices for resettling ethnic minority communities; to conduct intense monitoring and evaluations; to establish reliable mechanisms for grievances; and to improve accountability (McDonaldWilmsen 2009; McDonald-Wilmsen et al. 2011).

The experiences derived from development induced displacement and resettlement practice and the IRR model developed by Dr. Michael M Cernea were widely applied to other types displacement and migration practices such as climate migration, post-earthquake reconstruction and rehabilitation, ecological migration, environmental protection migration, conservation migration, poverty alleviation migration, preventing disaster migration etc. Since 2005, quite a lot of studies were conducted and have been published both in Chinese and English (Shi and Chen 2001; Yu 2002, 2018; Tang and Shi 2002; Shi 2011, 2015; Hu and Shi 2017; Xu and Shi 2017).

\section{Development Impact Assessment Policy and Practice: The Evolution of Social Assessments in China ${ }^{1}$}

China has increasingly relied during the last two decades on the useful tools of Social Impact Assessment (SIA) which under China's improved legislation must be carried out now for every Chinese development project.

The development of social assessment in China and its achievements are the result of the combined efforts of the Chinese government, international organizations like the World Bank, UK ODA and the Asian Development Bank, Chinese and international experts and scholars. It is a particular honor to be able to use our contribution to this volume in honor of Dr. Michael M Cernea to acknowledge his longstanding commitment to the development of social assessment in China and the

\footnotetext{
${ }^{1}$ This section summarizes the more detailed paper presented by Prof. Guoqing Shi at the Bieberstein Symposium and then also in Nanjing at the NRCR conference of March 2016 (see: Proceedings, Hohai Univ. Nanjing-Jiangsu, PRC, pp. 35-47).
} 
role that he has played in helping Chinese social scientists develop policies, standards, guidelines, skills, and operational experience.

As a specialized subject, the methodology of project social impact assessment was introduced and practiced first in western developed countries. ${ }^{2}$ Popularized widely after WW II, project assessments produced very useful results. ${ }^{3}$ Initially focused mainly on environment and technical variables, over time the pre-project assessments were usefully broadened to include also social impacts the overall project assessment framework and have been adapted to serve various types of project proposals and the trends in different countries and to the needs of various development agencies. As a result, there is no uniform definition for social assessment. For example, in the USA it is called "Social Impact Assessment" (SIA). In the United Kingdom it is called "Social Analysis." In international development, the World Bank was the first to institutionalize the use of "sociological analysis" in the preparation and the appraisal of its Projects, introducing it in 1984 as a mandatory operational policy (World Bank OMS 2.20) and employing the concepts or "social analysis" since 1984 (Cernea 2015). In 1995, the World Bank introduced also the equivalent concept of "Social Assessment" (see chapter "The Direct and Major Operational Relevance of Social Assessments" by Jonathan Brown, this volume). All these terms refer roughly to the same methodological approach, though there are some slight differences in emphasis between them.

In China, social assessment became a comprehensive framework that fits comfortably with all of these definitions. While the contents for specific projects differ due to each project's different objectives, users, and socio-economic environments, the main purpose, methods and tools of social assessment tend to be similar for all projects. Chinese social assessments for development projects cover a set of key topics, which were mainly contributed and proposed by Professor Guoqing Shi, as follows:

- Social Impact Analysis (SIA)

- Stakeholder Analysis

- Social Risk analysis

- Social Adaptation and Acceptance Analysis; and

- Social Sustainability Analysis

By carrying out the above sets of analyses, social assessments in China cover the full project cycle. They include not just an upfront "assessment", but also the preparation of a social management plan with measures and options for reducing the main social risks and adverse impacts.

The introduction and uses of social assessment in China reflect the broader changes in our country's development strategy and how the national policy makers and planners began to attach importance to issues of social development; meeting the

\footnotetext{
${ }^{2}$ Wang Yaoqi (2001). Assessment of Investment Projects. Beijing: China Financial Press.

${ }^{3}$ Henk Becher (1997). Social Impact Assessments: method and experiences in Europe, North America and the developing world. London: UCL Press: 24-26.
} 
people's basic needs were put forward as the main objective of development. Social assessment of investment projects came into use in China, and over time social assessments have become an integral part of the evaluation system of project management. While offering further an overview on how the new social assessment methods were taken up by China's officials and researchers, this paper will also discuss the contributions of the international community, and, in particular, Dr. Michael M Cernea's deep and longstanding engagement with China's development community for helping Chinese authorities and practitioners draw on global lessons as they developed their own vision and skills.

Compared to developed countries, China's interest in social assessment in China started relatively slow and late, since this became possible only after the abnormal years of the "cultural revolution". Even social research on investment projects in China began only in the mid-to-late 1980s, and developed only in the early 1990s. However, once launched, social researchers were able to conduct their work with high-level support.

The first major institutions that promoted the early research on projects' social assessment based on their own perceived needs were the Institute of Investment of the State Development Planning Commission and the Institute of Standards and Norms of the Ministry of Construction. Their work was strongly supported throughout by the very powerful State Commission for Development Planning. The initial results of this research were published as "Theory and Methods for Social Assessment of investment Projects" in August 1993. This inspiring book was the first monograph on Social Assessment published in Mainland China. It played an important role in spreading the idea, and in making known, the methods of SA.

The next key step in 1991 Sino-British inter-governmental cooperation project, supported also by the World Bank, was the first international technical assistance explicitly intended to build Chinese capacity for the assessment of investment projects. Two subtopics of this project were related to social assessment, namely: Social Analysis on Investment Projects and Social Policy. Their findings were published as the report on "Guidelines on Social Assessment for Investment Projects" in June 1997. It became one of the most influential monographs on social assessment for investment projects in China.

An important part of this China-UK cooperation project were the academic exchanges. During 1993 and 1994, China sent two delegations to the UK; the first consisted of five social researchers who conducted research on social assessment under the instruction of Prof. Alan Rew at Swansea University; the second group consisted of 20 high ranking officials from different line ministries who participated in 1994 in the UK in an Advanced Workshop on Social Assessment of Investment Projects. Further, in July 1995, the Government of China and the British Overseas Development Agency held in Beijing an "International Workshop on Social Assessment of investment Projects" to which China invited also the World Bank which delegated Dr. Michael M Cernea; from the UK, the participants were Elizabeth Croll, Peter Oakley, and Alan Rew.

This was the first time that an international workshop about SA was held in mainland China. Dr. Cernea introduced the second edition of his influential book 
"Putting People First: Sociological Variables of Development Projects". Learning about this book, China's Research Institute of Standards and Norms of the Construction Ministry decided to translate and publish Putting People First into Chinese, in order to make it available broadly in China to development practitioners and researchers. The main part of the translation work was carried out by Dr. Chaogang Wang, one of the co-authors of this present paper.

All these developments marked the start of China's adoption and work on social assessment for investment projects. The books mentioned above were published in the form of academic works, which is to say, without the endorsement of any related government departments. Therefore, the social assessment methodologies of SA described in the books merely represented the views of the books' editors. However, despite the lack of formal endorsement, they were readily available for researchers, consultants and decision-makers. The books mentioned above have been the most influential monographs on SA for investment projects in China.

The fundamental principle of putting people first in development projects has been accepted at the senior-most level of the Chinese Government. In his speech at the Central Party School on June 25, 2007, China's President Hu Jintao stated that the core of the scientific development perspective consists of "Putting People First".

Other government departments have in varying degree also done work on social assessment. The Planning Department of the Ministry of Water Resources and the Chinese Association of Water Resource Economics have jointly set up an expert group which has conducted systematic research on the theory and methodology of SA for water conservancy projects since 1990. In 1999, it published the first sectoral guidelines on SA for construction projects in China that are designed for a particular industry. Another example of the spread of social assessment is that the Civil Aviation Administration of China (CAAC), in 2000, also formally declared that analysis on regional and social impacts must become an important part of building new airport projects.

In 1999, the Chinese Ministry of Finance requested also the ADB for assistance in building capacity for social assessment to strengthen the planning, monitoring and evaluation of development investments. The focus of this capacity building was on poverty, gender, minority and resettlement risks analyses. It produced a draft Social Assessment Manual presented during a SA Workshop in Beijing in April 2002. The Manual was endorsed by National Development and Reform Commission and published in 2004. In October 2004, the International Workshop in SA on WB and ADB Financed Projects was held in Hohai University.

Since 2002, the Chinese Government has continued to develop its social assessment policy and guidelines and to request regular SAs for large-scale development projects. For example, comprehensive social assessments were conducted for the giant Three Gorges dam project, for the Xiaolangdi project, and for the ongoing South-North Water Diversion project, which currently is the largest water resources project ongoing in China and in the world. Between 2008 and 2010, China's urban sector also adopted detailed social assessment guidelines that integrate social assessment into urban development strategies, as well as making it a management tool throughout each stage of the urban project cycle. 
In May 2007, the National Development and Reform Commission (NDRC) issued the "Necessary Documentation for Project Application Reports". It requires that all application reports of development which are to be submitted for approval include Social Assessments. The status of the NDRC meant that social assessment had officially become a necessary part of application proposals for development projects. And the Chinese government's 12th Five-Year Plan for the National Economic and Social Development put forward that Social Risk Assessments would be required for all policies and key projects.

We have already signaled the significant impact that the Chinese translation of "Putting People First" had on the development of Chinese thinking on social impact assessment. As we emphasized in the first part of this paper, Michael's partnership with our research community has had a tangible impact on improving the lives of people displaced by large development projects. But just as important as Michael M Cernea's direct contributions to policy and projects was his role as a teacher and researcher dedicated to building up China's own national capacities. Since 1988, Michael joined an few intensive training workshops or gave guest lectures in China, where his lectures treated subjects such as how to prepare a resettlement plan, how to carry out vulnerability assessments, and what methods of monitoring would allow program managers to adjust plans to changing realities. These lectures were heard by a large number of Chinese officials, social researchers, practitioners, and students.

Of great significance for the increase of the Chinese leadership's requirement for using risk analysis in each pre-project social assessments was the 2012 decision of China's State Council to add to existing legislation on Social Impact Assessment a new mandatory pre-project analysis for investments in infrastructure: the analysis of political risks, specifically of "risks to social stability", to be done as a condition for approving any infrastructure project. China's leadership has been aware and strongly concerned about the risks of social unrest, This expanded the conventional use in China of SIAs, to the pre-project identification of potential political risks, incorporating into project design measures and mitigations for the prevention of risks to social stability. This high level State Council decision confirmed again Michael M Cernea's regular argument about the centrality of pre-project risk analysis in every social assessment.

Dr. Michael M Cernea continued to make visits to Hohai University and the National Research Center for Resettlement, and he was appointed as Honorary Professor of Hohai University and international scholar of our Institute for Social Development. He also lectured at Three Gorges University in Yichang, supported its new Reservoir Resettlement Research Center, and was recognized for his scholarly publications and development work by being appointed as Emeritus Professor of TGP University.

For sustainable development and to promote exchange with International Society of Social Impacts Assessment, a new Industry Sociology Committee under the Chinese Sociology Association was established in 2014. The committee covered all academic research on social impacts caused by all types of development and industry. The SA as sub-branch of sociology in MA and Ph.D program was developed in Hohai University since 2005. 


\section{Conclusion}

The social dimensions of development projects appeared as issues of central concern to China's national planners only after the 'Cultural Revolution', starting from the 1980s. In the ensuing 40 years there have been big, progressive changes in China's legal, planning, and operational approaches to the legislation and practice of population resettlement and social assessment.

China's knowledge and innovation have combined openness to learning from global experience with a practical emphasis on adapting what is appropriate and building up national skills and instruments. With national interest and a program to build China's own knowledge and skills, international cooperation was given the opportunity to have a very constructive function in China.

Dr. Michael M Cernea played a significant role in these developments, by his direct participation along many years in the planning and implementation of some of the China's largest development projects, by his sociological publications that influenced positively China's approaches to resettlement and to social assessments, and by devoting a good part of his work as the World Bank's Senior Adviser on social policies, and by his direct contributions as a scholar and a teacher to large cohorts of Chinese social scientists.

Acknowledgment The draws from the authors' paper at the Bieberstein Symposium, and at the NRCR Conference, March 2016, Nanjing (see Proceedings of NRCR, Hohai University) as well as from papers presented by Guoqing Shi at SfAA annual meetings in Pittsburgh (2015), Vancouver 2016, and at the World Bank, in 2014. Some information in this paper draws from studies by Shaojun Chen (2018), Yuefang Duan (2018), and Guoqing Shi (2018), listed in the references.

The authors also express their grateful thanks to Dr. Scott Guggenheim and Ms. Arielle Klein for their valuable assistance in editing and preparing this paper for publication.

\section{References}

Barth, F. (2003). The preventable calamities of forced resettlement: Reflections on the on the Ertan hydro-electric project in China. Egypt: Processed Library of Alexandria.

Cernea, M. M. (1990). Poverty risks from population displacement in water resources development. Harvard University-HIID: DDP 355; www.cabdirect.org/cabdirect/abstract/19916712675

Cernea, M. M. (1991). Involuntary resettlement: research, policy, and planning. In M. M. Cernea (Ed.), Putting people first (pp. 188-215). New York: Oxford University Press.

Cernea, M. M. (1997). The risks and reconstruction model for resettling displaced populations. World Development, 25(10), 1567-1589.

Cernea, M. M. (2000). Risks, safeguards, and reconstruction: a model for population displacement and resettlement. In M. Cernea \& C. McDowell (Eds.), Risks and reconstruction. Washington, DC: World Bank.

Cernea, M. M. (2004). Impoverishment risks, risk management, and reconstruction: a model of population displacement and resettlement. In UN symposium on hydropower and sustainable development, Beijing. 
Cernea, M. M. (2016). State legislation facing involuntary resettlement: Comparing the thinking in China and India on development-displacement. In F. Padovani (Ed.), Development-induced displacement in India and China (pp. 7-51). Lanham: Lexington Books.

Cernea, M. M., \& Maldonado, J. K. (2018). Challenging the prevailing paradigm of displacement and resettlement: Risks, impoverishment, legacies, solutions (pp. 45-56). Abington, NY: Routledge.

Chen, S. (2016a). A study of poverty risks based on involuntary resettlement of Chinese village dwellers. In Proceedings of National Research Center for Resettlement (NRCR). Hohai University, Nanjing.

Chen, S. (2016b). Discussion of resettlement cost externalization of water resource and hydropower projects. In Proceedings of NRCR, Hohai-University, Nanjing.

Chen, S. (2018). Cost externalization impoverishes resettlers: findings from hydropower projects.

China Academy of Sciences. (2012). Recommendation on strengthening development-relevant research work on resettlement engineering. Proposal to State Council.

China International Engineering Consulting Company, revised English version edited by Bettina Gransow, \& Susanna Price. (2007). Social assessment manual for investment projects in Chinaturning risks into opportunities. China Planning Press

Duan, Y. (2003). Theoretical and practical study of reservoir resettlement compensation. Wuhan: Huazhong University of Science and Technology.

Duan, Y. (2018). Investing in resettlement and benefit-sharing in China: new paradigm, approaches, challenges, and prospects. In M. M. Cernea \& J. K. Maldonado (Eds.), Challenging the prevailing paradigm of displacement and resettlement.

Hu, Z., \& Shi, G. (2017). Risk management on perverting disaster resettlement. Beijing: Science Press.

McDonald-Wilmsen, B. (2009). Development-induced displacement and resettlement: negotiating fieldwork complexities at the Three Gorges Dam, China. Asia Pacific Journal of Anthropology, 10(4), 283-300.

McDonald-Wilmsen, B., Webber, M., \& Yuefang, D. (2011). Development for whom? Rural to urban resettlement at Three Gorges Dam, China. Asian Studies Review, 35(1), 21-42.

Ministry of Housing Construction. (2011). The guideline of social assessment for municipal utilities construction projects. Beijing: China Planning Press.

Ministry of Water Resources of PRC. (2009, July 31). Specification on planning and design of land acquisition and resettlement for construction of water resources and hydropower project. Beijing, China.

National Council of Foundation of Nature Sciences. (2016, March). China Academy of Sciences. Water conservancy science and engineering. China Development Strategy. Beijing, China: Science Press.

NRCR. (1994). Proceedings of the international senior seminar on involuntary resettlement and rehabilitation. Nanjing: Hohai University Press.

NRCR. (2016, March). Proceedings of National Research Center for Resettlement (NRCR). Hohai University, Nanjing City, Jiangsu Province, PRC.

Padovano, F. (2016). Development-induced displacement in India and China: A comparative look at the burdens of growth. Lexington Books.

Shi, G. (1995). Reservoir resettlement system planning theory and application. Hohai University Press.

Shi, G. (Ed.) (1996). Resettlement and Development: World Bank resettlement policies and experiences (Vol. I). Translated from English by NRCR, Hohai Univ. Press, Nanjing.

Shi, G. (Ed.) (1998). Resettlement, rehabilitation, development (Vol. II). Translated from English by NRCR, Hohai UP, Nanjing.

Shi, G. (1999). Discussion on reservoir resettlement science. Journal of Advanced in Science and Technology in Water Resources, 1.

Shi, G. (2009). Discussion on resettlement science. In Advances in water resources and hydraulic engineering: Proceedings of the 16th IAHR-APD congress (pp. 1456-1462). Berlin: Springer. 
Shi, G. (2011). Resettlement rights and interests protection and government responsibility. Jilin People Press.

Shi, G. (2015, March 30). Past and future of social safeguards: How did China learn from the World Bank's and international experiences? In Presentation at SfAA Meetings, Pittsburgh.

Shi, G. (2018). Comparing China's and the World Bank's resettlement policies over time: the ascent of the 'resettlement with development' paradigm. In M. M. Cernea \& J. K. Maldonado (Eds.).

Shi, G., \& Chen, S. (2001). China resettlement policy and practice. Ningxia People Press.

Shi, G., \& Dong, M. (2003). A study on social assessment for investment projects. Journal of Hohai University (Social Sciences Series), 2003(2), 49-53.

Shi, G., Yu, F., \& Wang, C. (2016). Changes and achievements in policies and practices for resettlement and social assessment in China between 1980s to 2010s: contribution by Dr. Michael M Cernea. Proceedings of NRCR, Hohai University, 35-47.

Standard and Norms Institute of Ministry of Housing Construction. (2014). The social assessment manual for municipal utilities construction projects: cases of social assessment. Beijing: China Planning Press.

State Council of China. (2006). Regulation for land requisition, compensation and resettlement from large and medium water conservancy and hydropower projects.

State Council of China. (2017). Decision of the State Council to Amend the Regulation on the Land Expropriation Compensation and the Resettlement of Migrants for the Construction of Largeand Medium-Scale Water Conservation and Hydropower Projects.

Tang, C., \& Shi, G. (Eds.) (2002). Resettlement and development, Proceedings of the international symposium on resettlement and social development. Hohai University Press, Nanjing.

TGP Preliminary design. of Three Gorges Project Vol. IX; Inundation of reservoir and primary plan of relocating peoples' disposition draft.

World Bank. (1980). Social issues in involuntary resettlement under bank-financed projects. OMS 2.33. Washington, DC: The World Bank.

World Bank. (1984). Project appraisal. OMS 2.20. Washington, DC: World Bank.

World Bank. (1986). Operations issue in the treatment of involuntary resettlement. Operational Policy Note 10.08. Washington, DC.

World Bank. (1994/1996). Cernea, M. M., Guggenheim, S., Aronson, D., and van Wicklin, W. (Task Force) Resettlement and development: the Bank-wide review of projects involving involuntary resettlement 1986-1993. Washington, DC: World Bank.

World Bank. (2001). Operational Policy/Bank Procedures. 4.12, Involuntary Resettlement. Washington, DC: World Bank.

World Bank. (2010). China—Hubei Shiman Highway Project: ICR1409.

World Bank. (2017). Environmental and Social Framework: Setting Environmental and Social Standards for Investment Project Financing. Washington, DC: World Bank.

$\mathrm{Xu}$, Y., \& Shi, G. (2017). Sustainable livelihoods of losing the sea fisherman. Science Press.

Yu, W. (2002). Reservoir-induced resettlement and poverty reduction. In C. Tang \& G. Shi (Eds.), Resettlement and development, Proceedings of the international symposium on resettlement and social development. Nanjing: Hohai University Press.

$\mathrm{Yu}, \mathrm{W}$. (2018). Policy innovation of reservoir resettlement under urban-rural integration (pp. 678-681). Social Sciences Academic Press (China). Nanjing: Hohai University Press.

Zhou, X., \& Feng, X. (2002). Potential risks of poverty of rural resettlers of the Three Gorges. Statistics and Decision-Making, (2), 31-32. 
Prof. Guoqing Shi, Chinese, in October 1959, Professor, Founding Dean of Public Administration School of Hohai University (2004-2016), Director of Social Development Institute (2002-) and National Research Center for Resettlement (1997-). He received Bachelor's Degree in Water Conservancy and Hydropower in 1982 and Master Degree in Water Resource and Hydrology in 1989, in Hohai University, China. He worked in TU Delft, Netherlands as the resource person and Team Leader in IWRM during 2000 and 2003. Visiting Professor in University of Melbourne in August 2014.

$\mathrm{He}$ is one of main creators and member of International Displacement and Resettlement Network (IDRN) in 2000, the Chair of Membership Committee and Member of Boarding Committee (2010-2012) of IWRA. He is member of Sustainable Hydropower Council and Chamber of Emerging and Developing Countries Committee of International Hydropower Association (IHA). $\mathrm{He}$ is also International Member of Committee of Expert of Turkey's Ilisu Dam and HEPP Project from 2007 to June 2009, the International Panel Member of Dasu and Tabeila 4th Hydropower Project in Pakistan since 2012. He is an senior adviser of Resettlement Development Bureau of Three Gorges Dam Project Constriction Committee under State Council since 1993, Adviser of World Bank, Asian Development Bank since 1994, Member of IASFM, Founding Chairperson of Resettlement and Migration Committee of Chinese Sociology Association (CSA) and Vice Chairperson of Resettlement Committee of Chinese Hydropower Engineering Association(CHEA) etc.

His Academic fields include Involuntary displacement and resettlement, social and economic assessment, social development, applied sociology, land resources management, demography, management science and engineering, water economics and Integrated Water Resource Management (IWRM) etc.

He has involved the preparation of national and regional resettlement policies and legislation, decision making process in resettlement planning and policy of a number of huge projects such as Three Gorges DHPP project (1.3 millions displaced people) , Xiaolangdi Dam Projects (200,000 PAPs) and Danjiangkou Dam Projects (345,000 PAPs) etc. and more than 50 development projects fund by World Bank and Asian Development Bank. He was engaged in Ilisu Dam in Turkey, Murum DHPP project in Malaysia and Dasu DHPP project in Pakistan as the international resettlement expert. He created the new Major in Resettlement Sciences and Management $(\mathrm{Ph} . \mathrm{D}$ and Master) in China and is the first Professor in this science research field. He is well known expertise in Development caused Displacement and Resettlement in Asian and in the World.

He has compiled or written 20 books such as China Resettlement Policy and Practice, Theory and Application of Reservoir Resettlement System Planning, Resettlement and Development -Study on World Bank resettlement policies and experiences, etc., and released more than 400 articles. He has achieved 15 Advance Science or Social Science Awards at the level of national or province. He has got following titles successively, Special Award of State Council, Outstanding Teacher of Ministry of Water Resources, Model of Youth Researchers of Jiangsu Province, Outstanding Youth Scientists of Jiangsu Province, Youth Scientist Award of Jiansu Province.

Prof. Shi has supervised more than about $200 \mathrm{Ph} . \mathrm{D}$. and master degree students which include a few international students from USA, Ghana, Lao PDR, Kenya, Nepal, Tanzania, Pakistan, Iran, Cambodia, Viet Nam, Cameron and Bangladesh, etc.

Email: gshi@vip.126.com. gshi@hhu.edu.cn, Mobile :+86 13305183575

Address: NRCR, Hohai University, 8 Focheng Road Road, Nanjing, Jiangsu, 211100, China

Fangmei Yu, Female, born in 1984, Doctor in sociology, Assistant Professor of Nanjing University of Posts and Telecommunications. Her work focused on policy evaluation, social assessment, agricultural development, poverty and social safeguard. She was awarded Bachelor of Management by Hohai University in 2007 and received Ph.D degree in Sociology in 2014. She has done a few research projects on resettlement and social assessment at National Research Center for Resettlement (NRCR), Hohai University, China.

Chaogang Wang worked as Senior Social Development Specialist at World Bank headquarters in Washington DC. He holds a PhD in management and has worked for various government agencies 
in China before joining the Bank in 2000. Over the last 25 years Wang has worked on various social development issues including involuntary resettlement, social impact assessment and management systems, stakeholder engagement, community participation, cultural heritage, gender equity, and indigenous peoples. He drafted the first Social Assessment Guideline in China applied to large-scale government financed construction projects. He prepared the first Guide for Local Benefit Sharing in hydroelectric projects. He is author or co-author of Method and Parameters of Economic Evaluation for Construction Projects (1993, Chinese), Guideline of Social Assessment for Investment Projects (1996, Chinese); Appraisal of Development Projects in China: Theory, Method and Case Studies (1997, in Chinese), Economic Evaluation Method of Real Estate Project (1999, Chinese).

Open Access This chapter is licensed under the terms of the Creative Commons Attribution 4.0 International License (http://creativecommons.org/licenses/by/4.0/), which permits use, sharing, adaptation, distribution and reproduction in any medium or format, as long as you give appropriate credit to the original author(s) and the source, provide a link to the Creative Commons license and indicate if changes were made.

The images or other third party material in this chapter are included in the chapter's Creative Commons license, unless indicated otherwise in a credit line to the material. If material is not included in the chapter's Creative Commons license and your intended use is not permitted by statutory regulation or exceeds the permitted use, you will need to obtain permission directly from the copyright holder. 